\title{
Relationship Between Creativity and the Tendency of Choosing Entrepreneurship as a Career Among the Polytechnic Students in Malaysia
}

\author{
Sri Sumarwati \\ Faculty of Technical and Vocational Education \\ University Tun Hussein Onn Malaysia \\ Batu Pahat, Johor, Malaysia \\ sri_fatoni78@yahoo.com
}

\author{
Jailani Md. Yunos \\ Faculty of Technical and Vocational Education \\ University Tun Hussein Onn Malaysia \\ Batu Pahat, Johor, Malaysia \\ jailani@uthm.edu.my
}

\author{
Tee Tze Kiong \\ Faculty of Technical and Vocational Education \\ Sultan Idris Education University \\ Tanjong Malim, Perak, Malaysia \\ tktee@fptv.upsi.edu.my
}

\begin{abstract}
The purpose of this research is to analyze the relationship between creativity and the tendency of choosing entrepreneurship as a career among the polytechnic students in Malaysia. A total of 425 third semester polytechnic diploma students (PMKL, PMJB, PUO, PMJ, PMK, PSMZA, PMM, PBS and PPD) were selected as research samples using purposive stratified random sampling method. The modified TTCT instrument was used to identify the level of creativity and the level of tendency choosing entrepreneurship as a career among the respondents. Research results indicated that there are significant differences in the level of creativity and the level of tendency on choosing entrepreneurship as a career based on the category of polytechnic. The study also shows a positive relationship between the level of creativity and the tendency of choosing entrepreneurship as a career.
\end{abstract}

Keywords - creativity; entrepreneurship; career; polytechnic.

\section{INTRODUCTION}

Malaysia is a country that is rapidly developing and intends to become a developed nation by the year 2020 [1]. In the $20^{\text {th }}$ century, developed countries began to transform the industrial economy into the knowledge economy using creativity [2]. Thus, the development of a country is influenced by the creativity that belongs to the society whether it inherent as a new ideas or new technologies [3]. Entrepreneurship is a way of creative effort to develop new values, where the outcome could be benefited by the society [4]. Creativity value influences the entrepreneurial success in carrying out entrepreneurship [5]. Therefore, creative entrepreneurs are increasingly needed in Malaysia in the way to boost up the economic and to support the country to become a fully developed nation by the year 2020 . Thus, the objectives of this study are to:
- Analyze the level of creativity among the polytechnic students in Malaysia.

- Analyze the level of tendency on choosing entrepreneurship as a career among the polytechnic students in Malaysia.

- Identify the differences between students from METrO Polytechnics, Premier Polytechnics and Conventional Polytechnics on the level of creativity.

- Identify the differences between students from METrO Polytechnics, Premier Polytechnics and Conventional Polytechnics on the level of tendency choosing entrepreneurship as a career.

- Identify the relationship between creativity and the tendency of choosing entrepreneurship as a career among the polytechnic students in Malaysia.

\section{CONCEPTUAL FRAMEWORK}

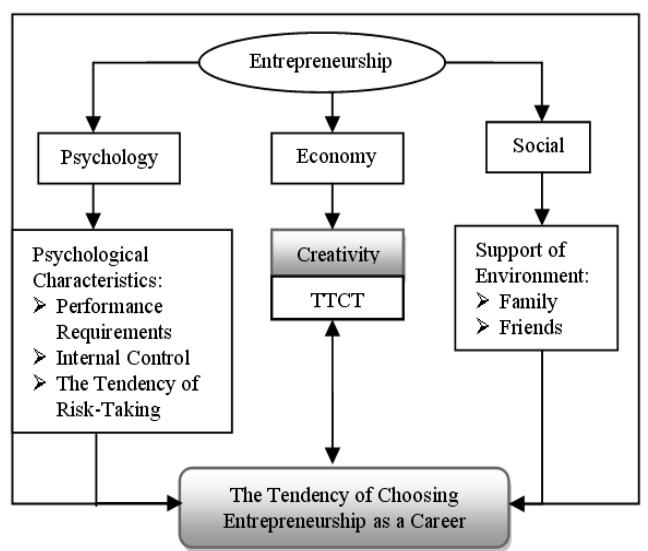

FIGURE $1 . \quad$ CONCEPTUAL FRAMEWORK 


\section{RESEARCH METHODOLOGY}

This is a survey study using the modified TTCT instrument to collect data from the respondents. Questionnaires were distributed through postal to the respondents.

\section{A. Population and Sampling Methods}

The target population for this study was the third semester polytechnic (METrO, Premier and Conventional) diploma students in Malaysia. Stratified random sampling [6] was applied in this study. Accurate sampling in the study was gained through purposive stratified random sampling [7]. The sample size between 30 and 500 was suggested if the samples are divided into several parts [8]. The determination of the sample with stratified sampling is shown in Table 1.

TABLE 1. DETERMINATION OF SAMPLE

\begin{tabular}{|l|l|l|l|l|l|l|l|}
\hline \multicolumn{2}{|c|}{$\begin{array}{c}\text { Poly- } \\
\text { technic }\end{array}$} & $\begin{array}{c}\text { Total } \\
\text { Number } \\
\text { of } \\
\text { Students }\end{array}$ & \multirow{2}{*}{$\%$} & \multicolumn{2}{c|}{$\begin{array}{c}\text { Proportionate } \\
\text { Stratified } \\
\text { Random } \\
\text { Sampling }\end{array}$} & \multicolumn{2}{c|}{$\begin{array}{c}\text { Purposive } \\
\text { Stratified } \\
\text { Random } \\
\text { Sampling }\end{array}$} \\
\cline { 5 - 9 } & & $\begin{array}{c}\text { Total } \\
\text { Sample }\end{array}$ & $\%$ & $\begin{array}{c}\text { Total } \\
\text { Sample }\end{array}$ & $\%$ \\
\hline 2 & $\mathrm{P}$ & 66 & 0.4 & 2 & 0.4 & 42 & 10.4 \\
\hline 3 & $\mathrm{C}$ & 14686 & 80.1 & 320 & 80.1 & 240 & 60.1 \\
\hline \multicolumn{2}{|l|}{ Total } & 18326 & 100 & 400 & 100 & 400 & 100 \\
\hline
\end{tabular}

IV. RESEARCH INSTRUMENTS

The questionnaire consists of three parts:

PartA. This section collects the respondents' demographic information.

PartB. This section consists of items which have been modified from the Torrance Tests of Creative Thinking (TTCT) instrument. The level of creativity is obtained based on the total marks from the criteria of originality, flexibility, fluency and elaboration.

PartC. This section of the questionnaire consists of 20 items with 5 Likert scale scores comprising the characteristics of entrepreneur and supportive environment, where the levels of tendency are evaluated based on the total marks from the related criteria.

\section{A. Pilot Study and Reliability of Research Instruments}

Pilot study was conducted at the Ibrahim Sultan Polytechnic with a total of 31 students. The reliablity values for the instrument are shown in Table 2.

TABLE 2. CRONBACH Alpha From The PILOT STUdy

\begin{tabular}{|c|l|c|}
\hline \multicolumn{1}{|c|}{ Category } & \multicolumn{1}{|c|}{ Criteria } & $\begin{array}{c}\text { Cronbach } \\
\text { Alpha }\end{array}$ \\
\hline \multirow{4}{*}{ Part B } & Originality & .912 \\
\cline { 2 - 3 } & Flexibility & .913 \\
\cline { 2 - 3 } & Fluency & .929 \\
\cline { 2 - 3 } & Elaboration & .917 \\
\hline \multirow{3}{*}{ Oart C } & .937 \\
\hline \multirow{2}{*}{ Overall the Value of Cronbach Alpha } & .912 \\
\cline { 2 - 3 } & Performance Requirements & .904 \\
\cline { 2 - 3 } & Internal Control & .891 \\
\cline { 2 - 3 } & The Tendency of Risk-Taking & .914 \\
\cline { 2 - 3 } & Family & .919 \\
\cline { 2 - 3 } & Friends & \\
\hline
\end{tabular}

\section{DATA Collection Methods}

Questionnaires were distributed by postal to polytechnics. 50 set of questionnaires were sent to the Metro Polytechnic and the total amount received by the researcher is 42 (99.9\%). 130 questionnaires were sent to the Premier Polytechnic and 121 (28.5\%) were returned. On the other hand, 363 questionnaires were sent to the Conventional Polytechnic and $262(61.6 \%)$ were collected back. In total, a sum of 425 questionnaires were received through the data collection process.

\section{DATA ANALYSIS AND FINDINGS}

SPSS for window is used to measure the frequencies, percentanges, differences and correlation (Table 3) for the research questions.

TABLE 3. SUMMARY OF RESEARCH QUESTIONS AND STATISTICAL TECHNIQUES USED IN THE STUDY

\begin{tabular}{|c|c|c|}
\hline Research Question & Statistics Design & Statistical Technique \\
\hline 1 & Descriptive & Frequency and Percentage \\
\hline 2 & Descriptive & Frequency and Percentage \\
\hline 3 & Intervention & One-Way ANOVA \\
\hline 4 & Intervention & One-Way ANOVA \\
\hline 5 & Intervention & Pearson-r \\
\hline
\end{tabular}




\section{A. The Level of Creativity Among The Polytechnic Students in Malaysia}

Total full marks for the criteria of originality, flexibility, fluency and interpretations are 60 marks. Levels of creativity are divided into four categories, which 0-12 marks indicates very low level, 14-28 marks indicates low level, 30-44 marks indicates moderate level and 46-60 marks indicates high level. The results from this study indicated that the level of creativity are 21 (4.9\%) students were at very low level, 193 (45.4\%) students at low level, $173(40.7 \%)$ students were at modereate level and only 38 (8.9\%) students were at high level. In summary, the results showed that in general, majoroty of the polytechnic students in Malaysia has a low and very low level of creativity.

\section{B. The Level of Tendency on Choosing Entrepreneurship as a Career Among The Polytechnic Students in Malaysia}

The total full marks for criteria of performance requirements, internal controls, the tendency risk-taking, family and friends is 100 marks. Levels of tendency are categorized into four, which 20-40 marks shows very low tendency, 41-60 marks shows low tendency, 61-80 marks shows moderate tendency and 81-100 marks shows high tendency. Based on these findings, the researchers found that a total of 25 (5.9\%) students are at the very low level of tendency choosing entrepreneurship as a career, 168 (39.5\%) were at low level of tendency, $192(45.2 \%)$ students were at moderate level of tendency and only 40 (9.4\%) students were at high level of tendency. Therefore, in general, the level of tendency choosing entrepreneurship as a career among the polytechnic students in Malaysia is at moderate and low level.

\section{Differences on The Level of Creativity based on The Category of Polytechnic \\ Hypotheses tested:}

Ho1: There are no significant differences in the level of creativity between the METrO Polytechnic, Premier Polytechnic and Conventional Polytechnic students.

The findings showed that the total number of respondents from the Conventional Polytechnic is 262 students, 121 students from Premier Polytechnic and 42 students from the METrO Polytechnic. In descending order, the total marks for creativity test obtained through the modified Torrance Tests of Creative Thinking for the Premier Polytechnic students is the highest with the mean score (38.347), METrO Polytechnic (32.524) and Conventional Polytechnic (27.954).

In addition, the results of the analysis variance test showed that the one-way ANOVA with value $p=.000$ is smaller than the value of $\alpha=.05$, therefore the null hypothesis is rejected. The results indicated that there are significant differences in the level of creativity between METrO Polytechnic, Premier Polytechnic and Conventional Polytechnic students. In addition, the post-hoc test with Bonferroni method for study pair's respondents which has caused the null hypothesis to be rejected. Finding pairs the comparative analysis using the Bonferroni method showed the mean level of creativity for Premier
Polytechnic and Conventional Polytechnic (mean difference = 10.3929, $\alpha=.05$ ) is significantly different.

\section{Differences on The Level of Tendency on Choosing} Entrepreneurship as A Career Based on The Category of Polytechnic

Hypotheses tested:

Ho2: There are no significant differences in the tendency of choosing entrepreneurship as a career between the METrO Polytechnic, Premier Polytechnics and Conventional Polytechnics students

In descending order, the results showed that the total marks for the tendency of choosing entrepreneurship as a career for the Premier Polytechnic is 72.231, METrO Polytechnic is 63.786 and the Conventional Polytechnic is 58.214 in mean score. Based on the one-way ANOVA result, the value $P=.000$ or less than $\alpha=.05$, then the null hypothesis is rejected. The analysis indicated that there were significant differences between the students from the METrO Polytechnic, Premier Polytechnic and Polytechnic Conventional in the level of tendency on choosing entrepreneurship as a career. While finding pairs comparative analysis using the Bonferroni method showed the mean level of tendency on choosing entrepreneurship as a career for Premier Polytechnic and Conventional Polytechnic (mean difference = 14.0177, $\alpha=0.05$ ) is significantly different. Students from the Premier Polytechnic have the higher tendency on choosing entrepreneurship as a career compared to students from the Conventional Polytechnic.

\section{E. Relationship Between Creativity and The Tendency of Choosing Entrepreneurship as a Career Among The Polytechnic Students in Malaysia \\ Hypotheses tested:}

Ho3: There is no significant relationship between creativity and the tendency of choosing entrepreneurship as a career among the polytechnic students in Malaysia.

When a positive correlation coefficient occurs, the higher the value $X$ was then the higher the value $Y$ will be and vice versa [9]. Based on the analysis, the coefficient correlation between creativity and the tendency of choosing entrepreneurship as a career $(r=.917)$ is positively high. This result indicates that the students with higher level of creativity tend to choose entrepreneurship as their career. 


\section{CONCLUSIONS AND RECOMMENDATIONS}

In conclusion, the polytechnic students are at the low level for both creativity and the tendency on choosing entrepreneurship as a career. On the other hand, there is a significant positive relationship between creativity and the tendency of choosing entrepreneurship as a career among the polytechnic students in Malaysia.

The low level of creativity and the moderate level of tendency on choosing entrepreneurship as a career among the polytechnic students could be improved by continuing efforts by all parties. Thus, the findings of this study are expected to assisst the lecturer, Department of Polytechnic Education and the Ministry of Higher Education on planning strategies to improve the level of creativity and the tendency on choosing entrepreneurship as a career among the students.

\section{REFERENCES}

[1] Said, M. M. M. and Yunos, N., "Peranan Guru Dalam Memupuk Kreativiti Pelajar”, MALIM: Jurnal Pengajian Umum Asia Tenggara, No. 9, pp 57-71. ISSN 1511-8393, 2008.
[2] Yuan, T. and Changchun, G., "Management Strategies of Creative Industries Uncertainty”, International Conference on Business Computing and Global Informatization, Shanghai China: School of Business Administration, Donghua University, pp 79-82, 2011.

[3] Syukri, M. R. and Zulkarnain, “Asertivitas dan Kreativitas Pada Karyawan yang Bekerja Di Multi Level Marketing, Psikologia, vol. 1 pp 54-62, 2005.

[4] Lambing, P. and Kuehl, C. R, Entrepreneurship, 2nd Edition, New Jersey: Printice Hall, 2000.

[5] Manaf, A. A., Omar, N. H. and Lee, K. Y., "Faktor Kritikal Kejayaan Usahawan Dalam Perniagaan”, e-BANGI: Jurnal Sains Sosial dan Kemanusiaan, vol 7, pp 34-45. ISSN 1823-884x, 2012.

[6] Wood, M. J. and Ross-Kerr, J. C., Basic Steps In Planning Nursing Research: From Question to Proposal, 7th Edition, United States: Jones \& Bartlett Learning, 2010.

[7] Gulo, W., Metodologi Penelitian, Jakarta: PT Grasindo, 2002.

[8] Roscoe, J. T., Fundamental Research Statistics for The Behavioral Sciences, 2nd Edition, New York: Holt, Rinehart \& Winston, 1975.

[9] Howitt, D. and Cramer, D., First Steps In Research and Statistics: A Practical Workbook for Psychology Students, London: Routledge, 2013. 